\title{
GUIDANCESHIP TRAINING BAGI PENDAMPING KAMAR SANTRI PONDOK PESANTREN PABELAN
}

\section{GUIDANCESHIP TRANING FOR COMPANION OF STUDENT ROOM PABELAN BOARDING SCHOLL}

\author{
${ }^{1)}$ Akhmad Liana Amrul Haq, ${ }^{2)}$ Aftina Nurul Husna, ${ }^{3)}$ Aning Az Zahra \\ ${ }^{1,2,3)}$ Fakultas Psikologi dan Humaniora Universitas Muhammadiyah Magelang \\ e mail: akuamrulhaq@ummgl.ac.id
}

\begin{abstract}
ABSTRAK
Guidanceship training ini bertujuan untuk membekali para pendamping kamar dalam menjalankan tugas kependampingan sebagai seorang kakak kelas, berdasarkan hasil survey awal kepada 137 santri didapatkan hasil bahwa 79\% santri (109 diantaranya) merasa tidak menemukan suasana yang nyaman di dalam kamar karena masih banyak keluhan dan masalah dari para anggota kamar yang belum tertangani oleh pendamping kamar. Untuk itu perlu diadakannya pelatihan kependampingan bagi para pendamping kamar untuk menunjang tugas memberikan keteladanan dan solusi terhadap berbagai masalah yang muncul pada adik-adik kelas anggota kamarnya. Terdapat 6 materi yang diberikan kepada para pendamping kamar pada guidanceship training ini antara lain materi tentang keteladanan, karakter remaja, konseling sederhana, 7 habits, kebersihan dan kesehatan serta problem solving and decission making. Hasil evaluasi guidanceship training menilai materi-materi apa saja yang dirasa paling bermanfaat untuk menangani berbagai permasalahan anggota kamar dan mudah diaplikasikan dalam menjalankan tugas kependampingan. Dari jumlah total 80 peserta pelatihan didatkan hasil bahwa 14 peserta $(17,5 \%)$ menganggap bahwa materi keteladanan merupakan materi yang paling aplikatif untuk bisa digunakan, 14 peserta $(17,5 \%)$ menganggap bahwa materi karakter remaja adalah materi yang mudah diaplikasikan, 8 peserta (10\%) menganggap bahwa materi konseling sederhana sebagai materi yang penting untuk dikuasai, 4 peserta (5\%) menganggap bahwa maeri 7 habit sebagai materi yang menarik untuk diterapkan, 17 peserta $(21,25 \%)$ menganggap bahwa materi kebersihan dan kesehatan adalah materi yang mudah untuk dijalankan dan 23 peserta $(28,75 \%)$ menganggap bahwa materi tentang problem solving and decission making merupakan materi yang paling aplikatif dalam menjalankan tugas sebagai pendamping kamar.
\end{abstract}

Kata kunci : Guidanceship, Pendamping, Santri

\section{ABSTRACT}

Guidancehip training aims to equip the chaperones in the task of sidewalk as an older sibling, based on the results of the initial survey to 137 students obtained the result that 79\% santri (109 of them) feel not find a comfortable atmosphere in the room because there are still many complaints and problems of the members of the room that have not been handled by the companion room. Therefore, it is necessary to provide the training of assistance to the companion of the chamber to support the task of providing exemplary and solution to the various problems that arise in the siblings of the class members of his room. There are 6 materials given to the counselors in the guidancehip training room include material about modeling, adolescent character, simple counseling, 7 habits, hygiene and health and problem solving and decission making. The results of evaluation of guidanceship training to assess what materials are considered most useful to handle various problems of members of the room and easy to apply in running the task kependampingan. Out of a total of 80 training participants, the 14 participants (17.5\%) assume that 
exemplary material is the most applicable material to be used; 14 participants (17.5\%) consider that adolescent character material is easy to apply, 8 participants (10\%) considered that simple counseling material as an important material to be mastered, 4 participants (5\%) considered that the seven habits as an interesting material to be applied, 17 participants $(21.25 \%)$ considered that the hygiene and health materials were materials that are easy to run and 23 participants $(28.75 \%)$ consider that the material on problem solving and decission making is the most applicable material in carrying out duties as chaperone.

Keywords: Guidanceship, Companion, Student

Submitted : 9 Mei $2018 \quad$ Revision: 18 Juli $2018 \quad$ Accepted : 23 Agustus 2018

\section{PENDAHULUAN}

Pondok Pesantren Pabelan memiliki \pm 200 santri putra dan \pm 200 santri putri, masuk dalam wilayah kabupaten Magelang, pondok pesantren pabelan memiliki kurikulum (KMI) Kulliyatul Mu'alimin Al-Islamiyah dengan masa studi enam 6 tahun, 3 jenjang MTs dan 3 jenjang MA. Terdapat 2 fokus masalah yang menjadi survey pada bulan September-Oktober 2017 yaitu masalah yang terjadi di asrama/kamar. Berdasarkan 137 santri yang mengikuti survey awal, didapatkan hasil bahwa 79\% santri (109 diantaranya) merasa tidak menemukan suasana yang nyaman di dalam kamar. Data diatas menunjukkan peran pendamping kamar di asrama belumlah optimal, karena masih banyak keluhan dari para santri yang belum tertangani oleh pendamping kamar.

Hidayat (2016) mengatakan bahwa pembentukan karakter santri di pondok pesantren sangat erat dipengaruhi oleh orangorang terdekat, pembiasaan yang dimunculkan untuk membentuk karakter santri yang kuat dapat dilakukan dengan cara pola hidup sederhana, menanamkan rasa persaudaraan dan persahabatan yang erat antar sesama santri. Untuk itu diperlukan adanya pelatihan guidanceship training bagi santri kelas $\mathrm{V}$ yang diberi tanggung jawab oleh pengelola pondok sebagai pendamping kamar. Materi-materi yang disampaikan dalam guidanceship training kepada para pendamping kamar antara lain materi tentang keteladanan, karakter remaja, konseling sederhana, 7 habits, kebersihan dan kesehatan serta problem solving and decission making. Pemberian guidanceship training bertujuan agar para pendamping kamar memiliki dasar-dasar ketrampilan memberikan layanan kependampingan kepada adik-adik kelas anggota kamarnya untuk menanamkan karakter positif, karena tugas dan fungsi pendamping kamar memiliki peran sangat penting sebagai pengganti orang tua santri di lingkungan asrama.

\section{METODE KEGIATAN}

Guidanceship training ini diiukuti oleh seluruh pendamping kamar santri pondok pesantren pabelan. Peserta yang terlibat dalam pelatihan ini berjumlah 80 pendamping dengan rincian 27 pendamping kamar santri putra dan 53 pendamping kamar santri putri. Terdapat 6 materi yang disampaikan dalam pelatihan ini antara lain keteladanan, karakter remaja, konseling sederhana, 7 habits, kebersihan dan kesehatan serta problem solving and decission making, Masing-masing materi disampaikan oleh narasumber yang berkompeten di bidangnya, setiap narasumber diberikan waktu 90 menit untuk menyampaikan materi dan tanya jawab. Metode penyampaian materi yang dilakukan kepada para peserta dengan cara ceramah kreatif, brainstorming, role play dan mini game. Adapun kelengkapan alat yang 
Akhmad Liana Amrul Haq, Aftina Nurul Husna, Aning Az Zahra Guidanceship Training Bagi Pendamping Kamar Santri Pondok Pesantren Pabelan

digunakan saat guidanceship training ini antara lain LCD proyektor, laptop, laserpoint dan lembar refleksi diri.

\section{HASIL DAN PEMBAHASAN}

Pemberian guidanceship training kepada para pendamping kamar santri pondok pesantren pabelan tahun ajaran 2017/2018 bertujuan untuk mempersiapkan para pendamping menjadi panutan dan teladan bagi adik-adik kelas anggota kamarnya. Gunarsa (1991) menjelaskan bahwa penting bagi seorang remaja memiliki lingkungan yang sehat, sehat secara fisik maupun secara psikis. Guidanceship training yang diberikan kepada para pendamping kamar meliputi 6 materi yakni keteladanan, karakter remaja, konseling sederhana, 7 habits, kebersihan dan kesehatan serta problem solving and decission making. Materi keteladanan yang diberikan dalam pelatihan ini menekankan kepada para pendamping untuk selalu memberikan contoh yang baik kepada anggota kamarnya, jangan sampai aturan-aturan yang dilarang oleh pesantren justru dilakukan oleh pendamping kamar.

Machsunah (2017) menjelaskan bahwa salah satu pembentuk karakter yang paling dominan adalah orang-orang yang hidup di sekitar anak, nilai pendidikan karakter dengan keteladanan para pengajar dan orang-orang terdekat sangat berpengaruh terhadap tumbuh kembang anak tersebut. Pemberian materi tentang karakter remaja di maksudkan untuk memberi wawasan kepada para pendamping kamar bahwa anggota kamarnya berada dalam masa remaja yang antara satu anggota dengan anggota lain memiliki sikap dan sifat yang berbeda-beda. Feisbien dalam Wening (2007) mengatakan bahwa remaja itu ditandai dengan datangnya masa pubertas, perubahan fisik yang menonjol dan gejolak psikologis.

Materi selanjutnya yang diberikan kepada para pendamping kamar mengenai konseling sederhana, hal ini dirasa penting diberikan karena sebagai pengganti orang tua para pendamping diharuskan berperan selayaknya orang tua yang dapat mendengar dan menasehati anggota kamarnya apabila mereka memiliki masalah, baik masalah yang bersifat individual maupun bersifat kelompok (Fauzan, 1994). Materi 7 habits yang diberikan kepada para pendamping kamar diharapkan bisa menjadi kebiasaan-kebiasaan positif dalam kehidupan sehari-hari yang selanjutnya ditularkan kepada anggota kamarnya. 7 habits yang diajarkan kepada pendamping kamar antara lain sikap proaktif, punya tujuan akhir, punya priotitas, berfikir menang, berusaha mengerti, bersinergi dan selalu mengasah kemampuan (Amrih, 2008).

Pendamping kamar santri pondok pesantren pabelan selanjutnya diberikan materi tentang kebersihan dan kesehatan, materi ini diberikan dengan tujuan untuk memberikan pengetahuan kepada para pendamping mengenai langkah-langkah pencegahan penyakit terutama kulit yang sering menjangkiti para santri. Ikhwanudin (2013) menerangkan bahwa respon santri terhadap perilaku kebersihan dan kesehatan masih kurang dipandang penting bila dilihat dari sudut pandang medis modern, hal ini disebabkan karena beberapa faktor antara lain santri masih mempertahankan diri dari penyakit dengan cara yang sederhana, dalam usaha memanfaatkan sistem kesehatan, santri mengacu pada pengetahuan kesehatan yang santri pahami dan perilaku kesehatan lingkungan santri dipengaruhi erat struktur dan nilai-nilai budaya serta nilai-nilai religi yang ada dipesantren tersebut.

Materi terakhir yang diberikan kepada para pendamping kamar tentang problem solving and decission making, pemberian materi ini bertujuan untuk membekali pendamping kamar dalam mengenali berbagai masalah yang kemungkinan terjadi di dalam kamar, pendamping kamar mampu menganalisis masalah dengan jalan berfikir sistematis, menggunakan fakta dan mencari 
Akhmad Liana Amrul Haq, Aftina Nurul Husna, Aning Az Zahra Guidanceship Training Bagi Pendamping Kamar Santri Pondok Pesantren Pabelan

alternatif solusi terbaik dan relistis (Hickson \& Khemka, 2013).

Aspek yang dievaluasi dalam pelatihan ini adalah aspek kebermanfaatan materi, hasil evaluasi di dapatkan dengan cara membagikan lembar evaluasi guidanceship training kepada seluruh peserta pelatihan. Aspek kebermanfaatan materi ini diukur dengan cara seluruh peserta diminta memilih satu materi yang dirasa paling aplikatif untuk diterapkan dalam kehidupan sehari-hari ketika menjalankan tugas sebagai pendamping kamar. Hasil evaluasi di dapatkan bahwa terdapat 14 peserta $(17,5 \%)$ yang menganggap bahwa materi keteladanan merupakan materi yang paling aplikatif untuk bisa digunakan, 14 peserta $(17,5 \%)$ menganggap bahwa materi karakter remaja adalah materi yang mudah diaplikasikan, 8 peserta (10\%) menganggap bahwa materi konseling sederhana sebagai materi yang penting untuk dikuasai, 4 peserta (5\%) menganggap bahwa maeri 7 habit sebagai materi yang menarik untuk diterapkan, 17 peserta $(21,25 \%)$ menganggap bahwa materi kebersihan dan kesehatan adalah materi yang mudah untuk dijalankan dan 23 peserta $(28,75 \%)$ menganggap bahwa materi tentang problem solving and decission making merupakan materi yang paling aplikatif dalam menjalankan tugas sebagai pendamping kamar.

Hasil evaluasi juga menemukan bahwa terdapat perbedaan yang menarik antara pendamping kamar putra dan pendamping kamar putri terhadap materi yang paling dianggap mudah untuk dijalankan. Dari total 53 pendamping kamar putri 18 pendamping diantaranya memilih problem solving and decission making sebagai materi yang mudah untuk diterapkan. Adapun dari total 27 pendamping kamar putra 6 pendamping memilih materi keteladanan yang paling mudah untuk dijalankan. Selain itu, terdapat perbedaan juga terhadap materi yang paling dianggap sulit untuk dijalankan sebagai pendamping kamar. Pendamping kamar putri memilih materi 7 habit karena tidak ada yang memilih dan 3 pendamping kamar putra merasa materi kebersihan dan kebersihan sebagai materi tersulit untuk diterapkan.

Pelatihan guidanceship training ini bertujuan untuk membekali para pendamping kamar dalam menjalankan tugas sebagai kakak kelas yang bisa menjadi contoh dan teladan adik-adik kelas anggota kamarnya. Hasil evaluasi pelatihan menunjukkan bahwa materi tentang problem solving and decission making adalah materi pertama yang dibutuhkan untuk diaplikasikan dalam menjalankan tugas kependampingan. Rochiyati (2011) yang mengatakan bahwa bimbingan teman sebaya dapat mempengaruhi perkembangan kepercayaan diri seseorang, artinya sebagai seseorang yang sebaya dengan anggota kamarnya, pendamping kamar harus mampu untuk memberikan alternatif solusi bagi permasalahan anggota kamarnya agar anggota kamarnya memiliki rasa percaya diri dalam mengambil keputusan ketika menghadapi masalah.

Materi tentang kesadaran menjaga kebersihan dan kesehatan merupakan materi kedua yang dibutuhkan untuk diaplikasikan dalam menjalankan tugas kependampingan para pendamping. Penanaman karakter hidup bersih dan sehat juga menjadi salah satu tujuan dilakukannya pelatihan guidanceship training ini, para pendamping kamar yang sudah mengikuti pelatihan ini diharapkan mampu untuk menanamkan nilai-nilai kebersihan dan kesehatan kepada adik-adik kelasnya karena karakter seseorang dibentuk oleh lingkungan, keluarga, teman sebaya dan sekolah dimana individu tersebut berada (Wening, 2007).

Keteladanan dan karakter remaja menjadi materi ketiga yang dibutuhkan pendamping untuk menjalankan tugas kependampingan, dengan mengedepankan keteladanan dan mengetahui berbagai karakter yang ada pada tiap anggota kamarnya para pendamping kamar diharapkan mampu untuk 


\section{SIMPULAN}

mencontohkan nilai-nilai moral seperti malu ketika tidak mengerjakan kewajibannya karena malu adalah cerminan manusia yang terdidik secara moral dan intelektual (Hayani, 2017).

Terdapat dua materi yang kurang dirasa dibutuhkan untuk menjalankan tugas kependampingan karena kedua materi ini dipilih oleh sebagian kecil peserta pelatihan guidanceship training ini, materi tentang konseling sederhana hanya dipilih oleh 8 peserta dari 80 peserta $(10 \%)$ dan materi 7 habit dipilih oleh 4 peserta dari 80 peserta (4\%). Meskipun 2 materi ini dinilai oleh peserta sebagai materi yang kurang aplikatif, namun seluruh materi pelatihan yang diberikan diharapkan mampu menjadi bekal para pendamping kamar membentuk anggota kamarnya menjadi manusia yang berkualitas menurut Al-Qur'an, hal ini sesuai dengan pendapat Mujiono (2013) yang menyebutkan bahwa manusia yang berkualitas menunurut Al-Quran adalah manusia yang beriman kepada Allah SWT, mempunyai ilmu pengetauan dan ketrampilan sehingga dapat bermanfaat bagi sesama umat manusia.

\section{DAFTAR PUSTAKA}

\section{Amrih, P. (2008). The 7 Habitss Of Highly Effective People versi Semar \& Pandawa.}

Fauzan, L. (1994). Pendekatan-Pendekatan Konseling Individual. Malang: Elang Mas.

Gunarsa, S. D. (1991). Psikologi Praktis: Anak, Remaja dan Keluarga. BPK Gunung Mulia.

Hickson, L., \& Khemka, I. (2013). Problem Solving And Decision Making. The Oxford Handbook Of Positive Psychology And Disability.
Berdasarkan uraian hasil dan pembahasan diatas, dapat disimpulkan : 1) Terdapat 6 materi pelatihan yang diberikan pada acara guidanceship training pendamping kamar santri yaitu materi tentang keteladanan, karakter remaja, konseling sederhana, 7 Habits, kebersihan dan kesehatan serta problem soving and decission making. 2) Guidanceship training sangat bermanfaat untuk bekal para pendamping kamar menjalankan tugas kependampingan. 3) Materi tentang problem soving and decission making adalah materi yang paling dibutuhkan untuk diaplikasikan dalam menjalankan tugas kependampingan, sedangkan materi tentang 7 habit menjadi materi yang kurang dirasa dibutuhkan untuk menjalankan tugas kependampingan. 4) Terdapat perbedaan antara pendamping kamar putra dan putri terhadap materi yang paling dianggap mudah untuk dijalankan sebagai pendamping kamar, pendamping kamar putri memilih materi problem soving and decission making sedangkan pendamping kamar putra memilih materi tentang keteladanan

Ikhwanudin, A. (2013). Perilaku Kesehatan Santri (Studi Deskriptif Perilaku Pemeliharaan Kesehatan, Pencarian Dan Penggunaan Sistem Kesehatan Dan Perilaku Kesehatan Lingkungan Di Pondok Pesantren Assalafi Al Fithrah, Surabaya). Jurnal Sosial dan Politik Departemen Sosiologi. journal.unair.ac.id/.../JURNAL\%20P ERILAKU\%20KESEHATAN. 
Machsunah, Y. C. (2017). Penanaman Pendidikan Karakter Melalui Keteladanan Pendidik (Studi Kasus di LBB Taman Pintar: Sahabat Sekolah Anak Lamongan). Edupedia, Jurnal Ilmu Sosial dan Humaniora, 1, (2), 59-65

Mujiono. (2013). Manusia Berkualitas Menurut Al-Qur'an. Jurnal Hermeunetik, 7, (2). 357-387

Hayani. N., (2017). Peran Rasa Malu dan Rasa Bersalah Terhadap Penanaman Moral Anak. Al-Irsyad, 8, (1), 42-54
Rohayati, I. (2011). Program Bimbingan Teman Sebaya untuk Meningkatkan Kepercayaan Diri Siswa. http://jurnal.upi.edu/file/36ICEU_ROHAYATI.pdf

Wening, S. (2007). Pembentukan Karakter Remaja Awal Melalui Pendidikan Nilai Yang Terkandung Dalam Pendidikan Konsumen: Kajian Evaluasi Reflektif Kurikulum SMP di Yogyakarta. Jurnal Penelitian dan Evaluasi Pendidikan.10, (2), 151-168 